Veres Pál-Golovics József

\title{
Az ingatlantulajdont éró negatív externáliák problémája a jogosultságok specifikációja és a tranzakciós költségek tükrében ${ }^{1}$
}

\section{The Problem of Adverse Externalities Affecting Real Properties in the Light of the Specification of Authorisations and of Transaction Costs}

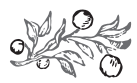

\section{Összefoglalás}

Jelen tanulmány az ingatlanokat éró negatív externáliák kérdésével foglalkozik. Amellett érvelünk, hogy a hazai gyakorlatban az ingatlanokra vonatkozó tulajdonjogok specifikációja nem kielégítô mértékú, ráadásul a jogérvényesítéshez kapcsolódó tranzakciós költségek mértéke is túlzott. Így az ingatlantulajdonosok - sok esetben kiegyenlítetlen „erôviszonyok” mellett - kénytelenek elszenvedni a negatív externáliák hatását. Tanulmányunkban az intézményi közgazdaságtan eszköztárának segítségével - ideértve a tulajdonjogok és a tranzakciós költségek elméletét, valamint a szerzôdések gazdaságtanát - tekintjük át a kérdésnek mind az elméleti, mind a hazai gyakorlatra kivetített vonatkozásait. A problémás pontok azonosítása után a lehetséges megoldási irányok felvázolására is kísérletet teszünk.

Dr. Veres Pál PhD, ny. egyetemi docens, Budapesti Corvinus Egyetem (pal.veres@uni-corvinus.hu), Golovics József, egyetemi tanársegéd, Budapesti Corvinus Egyetem (jozsef.golovics@uni-corvinus.hu). 
Journal of Economic Literature (JEL) kódok: D23, K11, K25, P14

Kulcsszavak: ingatlan, tulajdonjog, tranzakciós költség, negatív externália, szerzôdés

\section{Summary}

This paper discusses negative externalities affecting real properties. It is argued that in Hungary the specification of property rights to real estates is insufficient, and the transaction costs related to the enforcement of rights are excessive. For this reason, property owners suffer from negative externalities, frequently facing power imbalances. Using the toolbox of institutional economics, including the theory of ownership rights and transaction costs as well as the economics of contracts, the study gives an overview of both the theoretical and the practical considerations of this problem in Hungary's practice. Having identified the hot spots, an attempt is made at outlining pathways towards possible solutions.

Journal of Economic Literature (JEL) codes: D23, K11, K25, P14

Keywords: real property, ownership title, transaction costs, adverse externalities, contract

\section{BEVEZETÉS}

Tanulmányunk a lakóingatlanok vásárlásakor megszerzett tulajdonjog s az azzal járó tulajdonosi jogosítványok témájára fókuszál. A lakásvásárlás - különösen hazánkban széles tömegeket érintô kérdés: a KSH (2018) adatai szerint 2016-ban a lakások 90\%-át tulajdonosok lakták. Fontos kérdésnek tekinthetô, mi is az ingatlanok vásárlásakor szerzett tulajdonjogok tartalma, illetve ezek mennyire jól specifikáltak. A tulajdont érô, akár idôben késôbb jelentkezô külsô hatások - amelyeket a közgazdaság-tudomány externáliáknak nevez - ugyanis érdemben befolyásolhatják a tulajdonolt ingatlan valódi használati értékét, ezáltal a tulajdonos jólétét.

Tanulmányunkban tehát arra a kérdésre keressük a választ, hogy a hazai gyakorlatban a lakóingatlan-vásárláskor szerzett tulajdonjogok - közgazdaságtani szempontból - megfelelően specifikáltak-e ahhoz, hogy alapot teremtsenek az ingatlant érô negatív externáliák kezeléséhez. Álláspontunk szerint nem, ezért vizsgálandó, hogy a konkrétabb specifikáció milyen esetleges pozitív, illetve negatív hatásokkal járna, s mennyiben segítene hozzá a külsố gazdasági hatások decentralizált - az érintettek közötti alku, illetve megállapodás révén történő - megoldásához. Ezzel párhuzamosan egy esetlegesen nagyobb mértékú makroszintú (állami, önkormányzati) jogi védelem kérdése ugyancsak elemzésünk tárgyát képezi. További bátorítást adott, hogy több, a téma szempontjából releváns problémát (aszimmetrikus információ, tranzakciós költségek, az ingatlan külső környezetének, a tulajdonost védó jogszabályok és egyéb formális és informális intézmények fontossága) az amerikai helyzetre vonatkoztatva már North (2010) is felvetett. 
A témaválasztás fó motivációja a tanulmány egyik szerzőjének „résztvevô megfigyeléséből" adódik, nevezetesen egy több mint 30 éve lakott ingatlan tulajdonosi jogosítványait érintô, a tulajdonostól független külsố változások észlelésébôl, következményeinek - konfliktusainak, költségeinek, megoldatlanságának - viseléséből. A három évtizeddel ezelốtt zöldövezetben épült társasház környezeti tényezôiben van, ami többnyire változatlan maradt, részben javult is: itt említhetố a közbiztonság, az oktatási, egészségügyi közszolgáltatások infrastruktúrája, a tömegközlekedés elérhetôsége. Utóbbi kiszámíthatósága és kényelme szempontjából kifejezett javulás történt, ahogyan az M0-s körgyưrú új szakaszának átadása nyomán keletkezô új útvonal-lehetôségek megjelenése is pozitívumként értékelendô. Ezzel szemben a korábban zaj- és légszennyezés szempontjából kifejezetten csendes, egészséges környéken mára a közeli új Duna-híd átadása s a környék egyre sû́rúbb beépítése drasztikusan megemelte az átmenố autóforgalmat és ezzel a zaj-, illetve légszennyezési szintet. A gazdaság növekedésével párhuzamosan az átmenô forgalom egy része a környéken megállt, és mára szabályozatlan, anarchikus parkolási viszonyok alakultak ki. Az utóbbi hónapokban továbbá - bár a társasház Budapestnek a repülôtértôl egyik legtávolabb esố területén helyezkedik el - drasztikusan megemelkedett a le- és felszálló repülőforgalom, az elviselhetetlenség határát súroló zaj- és légszennyezéssel. A konkrét esetben bekövetkezett változások rövid felvázolása arra kíván utalni, hogy ilyen vagy az eredetileg szerzett jogokat akár súlyosabban érintố hatások bárhol és bármikor sújthatnak tulajdonosokat. A teljesség igénye nélkül leírt eset azt is mutatja, hogy az externális hatások magán-, önkormányzati és állami szereplókhöz (mint okozókhoz) egyaránt köthetôk.

Mindezek együttese a téma vizsgálatára és jelen tanulmány megírására ösztönzött bennünket. Célunk, hogy elindítsunk egy gondolkodást a lakóingatlanokra vonatkozó tulajdonosi jogosítványok pontosabb (lényegi tartalmi) specifikációjáról és ezek jogszabályi védelmérôl. Ehhez a tulajdonjogok - többek között Coase (1960), Demsetz (1967) és Pejovich (1992) munkássága nyomán kifejlődô - közgazdasági elmélete, valamint az intézményi közgazdaságtan további vívmányainak (többek között a szerzódésekre, tranzakciós költségekre, opportunizmusra vonatkozó elméletek) felhasználása lesz segítségünkre. ${ }^{2}$ Elemzésünk módszere az elméletalkalmazáson nyugszik, s ennek nyomán értékeljük mind a jelenlegi helyzetet, mind a lehetséges változtatási opciókat. Jóllehet az ingatlantulajdont nemcsak negatív, hanem pozitív externáliák is érhetik, amelyek kezelésének kérdése ugyancsak tudományos érdeklôdésre tarthat számot, a terjedelmi korlátok okán ezek tárgyalása nem képezi jelen írás tárgyát.

A tanulmányunk öt fố szerkezeti egységre oszlik. A bevezetést követôen bemutatjuk témánk elméleti hátterét, majd az ingatlanra vonatkozó tulajdonjogok specifikációjának egy tiszta esetét vázoljuk fel. Ezt követően a hazai lakóingatlanok tulajdonjogi viszonyaira vonatkozó jelenlegi helyzetet tekintjük át a vonatkozó intézményi közgazdaságtani elméleteken keresztül, ami alapján a következô részben a lehetséges intézményi védelem kérdését tárgyaljuk. Végül a következtetések összegzésével zárjuk tanulmányunkat. 


\section{Elméleti hátTÉR}

Az intézményi közgazdaságtan tulajdonjogokra vonatkozó elmélete többek között a jogosultságok természetével és funkciójával, a jogok pontos definiálásának kérdésével, továbbá a különbözố tulajdonformák történeti fejlődésével, illetve összehasonlító elemzésével foglalkozik (bővebben lásd Golovics-Veres, 2019; Pejovich, 1992). A közös tulajdonú javak esetén a kizárhatóság hiánya és a közös használatból eredô externáliák felmerülése jelenti a fố problémát. Ez teremtette meg a motivációt a történelem során a magántulajdon megjelenésére és elterjedésére (Demsetz, 1967). A lakóingatlanok kapcsán többnyire ezzel a tulajdonformával találkozunk. Persze ez sem tekinthetố kizárólagosnak, hiszen Magyarországon is találkozhatunk osztatlan közös tulajdonú ingatlanokkal, s a magántulajdonban lévô ingatlanokhoz is tartoznak vagy kvázi tartoznak (de jure vagy de facto) bizonyos közös tulajdonú részek. ${ }^{3}$

Az externáliák problémája ugyanakkor a magántulajdon esetén is megjelenhet, amennyiben a jogok nincsenek megfelelóen specifikálva (Coase, 1960). Ezek olyan külsố gazdasági hatások, amelyek nem a piacon keresztül realizálódnak, s rajtuk keresztül egy gazdasági szereplő akár pozitív, akár negatív irányban befolyásolja egy másik szereplő jólétét. Az ingatlantulajdon esetén ilyen lehet például, ha az egyik szomszéd elviselhetetlen zajjal zavarja a másikat. A jóléti közgazdaságtan automatikus válasza az externáliára az állami beavatkozás révén történố tiltás és a büntetés volt, mondván, annak okozóját korlátozni kell a másik védelmében. Coase azonban felhívta a figyelmet, hogy ez nem feltétlenül vezet Pareto-hatékony eredményhez, ráadásul nem is önmagában az externália léte jelenti a problémát. Rámutatott, hogy egy alacsony tranzakciós költséggel terhelt környezetben a felek alku révén is kezelhetnék az externáliát, ha a tulajdonjogok megfeleló módon specifikálva lennének. A gyakorlatban azonban pontosan ezek hiánya figyelhetố meg: a jogok s azok pontos tartalma nincs tisztázva, ráadásul az alkuk megkötése, a jogok érvényesítése is rendkívüli mértékú tranzakciós költséggel járhat. Az elôbbi példával élve, gyakran nem világos, kié a jog: az elsố szomszédnak áll jogában zajt csapni, vagy a másodiknak van joga a nyugalomhoz - s ha még ez egyértelmú is lenne, a jog bírósági úton történô kikényszerítése hatalmas költséggel (ideértve a lehetôségköltségeket is) járna. Ezen körülmények azonban alapjaiban ássák alá az externáliák alku révén történố megoldásának a lehetôségét, hiszen gyakran még a kiinduló helyzet sem tisztázott a felek számára.

Externáliák azonban - mint azt a bevezetésben szemléltettük - nem csak a vásárlás idôpontjában érhetik a lakóingatlanokat: késôbb újabbak is megjelenhetnek. Azonban ezek alku révén történố kezelése is csak akkor képzelhetố el a fentiek alapján, ha a tulajdonjogok, illetve a megszerzett jogosultság tartalma - amihez elengedhetetlen az érintett ingatlan paramétereinek pontos ismerete - a tranzakció lebonyolításakor pontosan specifikáltak a szerzôdésben. A pontosabb specifikáció azonban kétségkívül több tranzakciós költséget is eredményez (Hart, 2006; Williamson, 1985), így az egyes alternatívák mérlegelésében ezek mértéke is fontos szempontként jelenhet meg. Amennyiben ugyanis a jog tartalmának mérésével, illetve a tulajdonjogok spe- 
Veres Pál - Golovics József: Az ingatlantulajdont érô negatív externáliák problémája...

cifikálásával kapcsolatos tevékenységek irreálisan magas költségekkel járnának, úgy az kiolthatja az abból származó késôbbi (potenciális) előnyöket is.

\section{TULAJDONOSI JOGOSÍTVÁNYOK LAKÓINGATLAN VÁSÁRLÁSAKOR: EGY TISZTA ESET}

A fejezetben alapvetően Golovics és Veres írása (2019) alapján tekintjük át, hogy milyen tulajdonosi jogosítványokat szerzünk, illetve szerezhetünk egy lakóingatlan megvásárlásakor. Tiszta esetként azt feltételezzük, hogy az eladó valamennyi tulajdonosi jogosítvánnyal rendelkezik, és az ingatlan vásárlásakor a vevố szándéka, illetve az adásvételi szerzôdés szerint az eladó valamennyi tulajdonosi jogosítványa a vevốre száll.

Mielótt sorra vennénk ezeket a jogosítványokat, fontosnak tartjuk hangsúlyozni, hogy az ingatlan-tranzakciók a valóságban nem „ideális” körülmények között mennek végbe. Gyakran kényszerítô, sürgetô körülmények gátolják a körültekintố és alapos szerződéskötést, s a partnerek hajlamosak a tranzakciós költségek rövid távú megtakarítására (például az anyagi kényszer vagy valamilyen sürgetố határidôk miatt), amely hosszabb távon nagyobb tranzakciós költségeket és/vagy haszonveszteséget okozhat.

A tranzakció során megszerezhetố jogosítványok a következôk:

a) Az ingatlan a vevố birtokába kerül egy formális aktussal. A jog és a szerzódés szempontjából a vizsgálatunk fókuszában álló kérdés a birtokbavétel utáni birtoklás zavartalansága és sérthetetlensége. Ebben a tekintetben a birtoklás jogának specifikációja azt jelenti, hogy elôretekintve korlátlan vagy korlátozott (birtoklási) jogot szerzett-e a vásárló. Van-e, lehet-e olyan jogszabály vagy más szerződéses kötelezettség, amely késôbb harmadik szereplố számára birtoklási jogosítványt biztosít? Kiegészíthetjük ezt még olyan környezeti változásokkal, amelyek a zavartalan birtoklásra nézve kockázatot jelenthetnek.

b) Az adásvétel lezárultával, a birtokbavétellel kezdôdhet a megszerzett használati jog realizálása, az ingatlan használata. Tanulmányunkban ezt a jogosítványt tekintjük a specifikáció szempontjából leginkább kritikusnak. Mit is jelent a használati jog a gyakorlatban? A teljesség igénye nélkül az alábbi használati dimenziókat emeljük ki:

- Az ingatlan müszaki paramétereinek élvezete, így a hô- és hangszigetelés, szellôzés, ellenállás az idôjárási behatásoknak (beázás, szélerôsség, villámvédelem, alulról vizesedés), betörésvédelem, energiaellátás, vízellátás és szennyvízkezelés stb. „használata”. A múszaki jellemzốk szavatossági ideje - „normál” használat és „külsô” beavatkozás nélkül - ugyancsak fontos paraméterként említhetô. A teljesség igénye nélkül felsorolt jellemzốk pontos rögzítése (jogosítvány specifikálása) szükséges lehet a szerzôdésben, hogy a késôbb jelentkezô múszaki problémák esetén a probléma forrása, a felelôsség dedikálható legyen.

- Környezeti jellemzốk. Az ingatlan használatát érintố számos környezeti jellemzó pontos rögzítése ugyancsak szükséges lehet a szerzôdésben, és ezek védelmére a jogrendszerben is szükség lehet. Ilyenek a teljesség igénye nélkül: időjárási jellemzôk, külsố zajhatások a nap különbözố szakaszaiban, a légszennyezettség a nap különbözô szakaszaiban, közlekedési lehetôségek, oktatási, egészségügyi, szociális stb. szolgálta- 
tások (meglévook és tervezettek), közbiztonsági helyzet, az adott környezetben lakók társadalmi státusa, szociális, kulturális jellemzői, állattartási lehetôségek, környezeti hatással járó vállalkozási tevékenységek stb.

Bátran állítható, hogy teljességre törekvô specifikáció és védelem a felsorolásban jelzett használati jellemzók tekintetében sem a hatályos jogban, sem a szerzódésekben nincsen.

c) A lakóingatlan tulajdonos általi használata (lakás) mellett az ingatlan egyéb hasznosítási joga is megszerezhető. Ennek több formája is lehetséges. Három hasznosítási formát emelünk ki:

- Bérbeadás jövedelemszerzési céllal. A bérbeadás mint a birtoklás és használat jogának tranzakciója egy olyan jogosítványa a tulajdonosnak, amelynek korlátait a lehetó legpontosabban szükséges a szerzôdésben rögzíteni. Lehet általános jogszabályi korlát, helyi (önkormányzati) szabályozás, de fontosak az adózási, illetve bérleti díjra vonatkozó szabályok, továbbá magára a használatra vonatkozó, lakó- és egyéb környezeti korlátok.

- Késôbbi értékesités (ami akár a vásárlás fố motívuma lehet). Tisztázandó és rögzítendő, hogy van-e bármilyen értékesítési korlát (akár csak elôvételi jog) a jelenben, vagy már ma ismert jövốre vonatkozó döntés, terv.

- Üzleti (vállalkozási) célra történô hasznosítás. Ha a vevônek ilyen szándéka van, fontos annak tisztázása, hogy van-e ilyen lehetôség, s ha igen, milyen korlátokkal.

d) Az ingatlan átalakitásának joga. Az átalakítás joga szükséges lehet a használati jellemzôk javítása, a hasznosítás (bérbeadás), késôbbi (haszonnal) értékesítés szándéka esetén. Az átalakításnak azonban számos, a tranzakció idején már meglévô akadálya lehet. A teljesség igénye nélkül: múemlékvédelmi, beépítésre, magasságra stb. vonatkozó jogi korlátok, más érintett tulajdonosok jogosítványai, az ingatlan múszaki paraméterei stb. Ezen korlátok pontos szerzôdéses rögzítése a gyakorlatban gyakran hiányos lehet - többek között akár az eladó opportunizmusa miatt is (Williamson, 1985). Miként a korábban tárgyalt jogosítványok esetén, a jövőben az átalakítás tekintetében is érdemi korlátok - vagy éppen új lehetôségek - jelentkezhetnek. A kérdés itt is az, hogyan lehet és kell specifikálni - idóbeli érvényessége tekintetében is - a jogokat és korlátokat, ezek milyen feltételekkel és következményekkel szúkíthetôk vagy akár üresíthetôk ki, s hogyan lehet „védeni” a késóbbiekben a tulajdonos tranzakció során szerzett jogosítványait.

e) Az ingatlan elidegenitésének joga. Ezt a jogosítványt már említettük az ingatlan hasznosításának jogával kapcsolatban. A tulajdonjogok elmélete alapján (amikor jogosítványok csomagjáról beszélünk) a kérdés úgy is felmerül, hogy a tulajdonos azon jogosítványokat tudja elidegeníteni, amelyekkel rendelkezik, és olyan tartalommal, amely megfelel részben a jogi, részben a tényleges, illetve nagy valószínúséggel várható helyzetnek. Ez ismét és különösen kiemeli a jogosítványok pontos specifikációjának, illetve a jogosítványok tartalmában bekövetkezett, illetve várható változások követésének, illetve követhetőségének fontosságát.

Az eddig kifejtettek alapján az ingatlan (a rá vonatkozó jogosítványok) elidegenítésének lehetséges korlátjai aktuális és várható jogszabályi, birtoklási-használati (pl. haszonélvezeti), átalakítási és hasznosítási korlátozások lehetnek. A vevô szempontjából 
Veres Pál - Golovics József: Az ingatlantulajdont érő negatív externáliák problémája...

természetesen az aktuális és a nagy valószínúséggel várható helyzet ismerete, illetve a szerzôdésben történô pontos specifikálása - mint árbefolyásoló tényezô - alapvetô fontosságú.

Egy ingatlanra mint dologra vonatkozó tulajdonjogokat a fentiekben azok közgazdasági tartalma tekintetében vizsgáltuk. A tulajdon mint jogviszony jogi megközelítése a tulajdonos és mindenki más viszonyát vizsgálja a jog tartalma tekintetében (részletesen lásd Bartus-Szalai, 2014; Golovics-Veres, 2019; Hohfeld, 1913; 1917/2000). Ezen társas viszonyokra vonatkozó jogosultságok a következók:

a) A tulajdonos igényjoga mindenki más kizárását jelenti a jogosultságok gyakorlásából.

b) A tulajdonos privilégiuma vagy szabadsága azt jelenti, hogy a tulajdonos maga döntheti el, kíván-e élni és milyen módon jogosultságaival.

c) A tulajdonos hatalma abban áll, hogy jogosultságaival más tekintetében is rendelkezhet (jogokat átadhat, kötelezettséget vállalhat).

d) A tulajdonos mentessége vagy immunitása abban áll, hogy jogosítványainak tartalmát mások (a nem tulajdonosok) egyoldalúan nem változtathatják.

Témánk és kutatási célunk szempontjából a tulajdon mint dologi jogosultság mindkét dimenziója, tehát a jogosultságok tartalma, valamint a tulajdonos és mindenki más viszonya egyaránt fontos. A tartalom minél pontosabb meghatározása az alapja a jogviszony minél pontosabb meghatározásának, ez pedig annak, hogy a jogosítványok megszerzése után bekövetkezô externális hatásokat pontosan azonosítani (lehetôség szerint mérni) és kezelni lehessen.

A TULAJDONOSI JOGOSÍTVÁNYOK LAKÓINGATLAN VÁSÁRLÁSAKOR: A GYAKORLAT AZ INTÉZMÉNYI KÖZGAZDASÁGTAN SZEMSZÖGÉBÓL

A megfelelő specifikáció hiánya, illetve a szerzett jog tartalmának minél pontosabb rögzítése a hazai gyakorlatban is alapvetô gátját képezi az externáliák kezelésének. Az ingatlan vásárlásakor kötött adásvételi szerzôdés ugyanis általában nem rendelkezik részletekbe menően a megszerzett jog tartalmáról, amihez a megvásárolt ingatlan paramétereinek pontos ismerete is elengedhetetlen lenne. Bár a szerzódések rendre tartalmaznak információt az ingatlan jellegéről, méretérôl vagy a vonatkozó melléklet révén annak energetikai állapotáról, ám számos, a használati értéket ugyancsak érdemben meghatározó tulajdonságról (például zajszint, légszennyezettség, környezeti biztonság) nem, noha ezek egy része elviekben mérhetô, operacionalizálható lenne.

A jogosultságok pontos definiálásában a magasabb szintú intézmények sem feltétlenül adnak támpontot az externáliák kezeléséhez. A lakóparkok, társasházak házirendje, bizonyos önkormányzati rendeletek, illetve egyéb jogszabályok elviekben szolgálhatnak ugyan iránymutatással, ám ezek specifikáltságának foka széles skálán mozog (vö. például a zajterhelésre vonatkozó 27/2008. (XII. 3.) KvVM-EüM együttes rendeletet az egészséges környezethez való alkotmányos joggal).

A fentiek tükrében tehát a vevô sok esetben nincs tisztában a vásárolni kívánt jog valódi tartalmával, s ezáltal annak használati értékével, így rendre ki van téve az in- 
formációs előnnyel bíró eladó ex ante opportunizmusának (Williamson, 1985). Ez az információs aszimmetriával terhelt helyzet pedig felvetheti az állami beavatkozás lehetőségét (Weimer-Vining, 2011), például azáltal, hogy az adásvétel feltételeként jogszabályi eszközökkel kötelezôvé tegye - az energetikai tanúsítványhoz hasonlóan az ingatlan bizonyos további paramétereinek mérését és rögzítését. ${ }^{4}$ Ilyen lehetne egy, az ingatlan átlagos, továbbá napszakonként változó zajszintjére, légszennyezettségi jellemzőire vonatkozó mérési eredmény, vagy akár a környék közbiztonsági helyzetét leíró statisztika mellékelése.

Az intézkedés potenciális előnyei között egyrészt a fent nevesített információs aszimmetria csökkentését említhetnénk. Emellett a rögzített paraméterek kiindulási alapot képezhetnének egy, a késôbbiekben megjelenô külsô hatás alku révén történô kezelésében is: az idôvel beálló változások tárgyalása során - legyen szó akár pozitív, akár negatív externáliáról - ez jelenthetné a viszonyítási pontot.

A negatívumok kapcsán elsóként a tranzakciós költségek növekedése emelhetó ki: ilyen típusú mérések előírása további érdemi terhekkel sújtaná az egyébként is sok tranzakciós költséggel járó ingatlan-adásvételeket. Ez a vevoonek és az eladónak egyaránt kellemetlenséget okozhatna, különösen akkor, ha a tranzakcióban egyébként is jelen van valamilyen kényszerúségi motívum, vagy ha annak gyors lebonyolítása valamilyen okból kifolyólag fontos lenne. Emellett a szabályozással új járadékforrás keletkezne, amely járadékvadász-tevékenység megindulásához vezetne (Tullock, 2005): a mérések elvégzésére egy új „iparág” jönne létre, amely azonban a profitabilitását nem valamilyen valós piaci teljesítménynek, hanem pusztán a kormányzati aktusnak köszönhetné. Az elméleti megfontolásokon túl gyakorlati oldalról pedig - merítve az energetikai tanúsítvánnyal kapcsolatos, kétségkívül szelektív, de több esetben negatív tapasztalatból - a mérések megbízhatósága (gondolván például a mögöttük lévô tényleges szakértelemre, opportunizmus, összeférhetetlenség lehetőségére) is vita tárgyát képezhetné.

Mindezek figyelembevétele mellett az alku, illetve a jogérvényesítés során is komoly nehézségek adódnának. Amint ugyanis kifejtettük, az externáliák decentralizált kezeléséhez az alacsony tranzakciós költséggel terhelt környezet is szükséges feltétel. Ez azonban az általunk tárgyalt kérdésben nem áll fenn (különösen úgy, hogy az ingatlanokat érố külsô hatások esetében gyakran egyenlótlen „eróviszonyok” vannak az érintett felek között, általában az externália okozója „javára”). Ez potenciálisan olyan magas tranzakciós költségeket is jelenthet, amelyek mellett a negatív externália elszenvedôjének már reménytelennek túnhet a megegyezés elérése, de hasonló megállapítás tehetô a jogos igények bírósági úton történô érvényesítése kapcsán is. Ilyen körülmények között egy magánszemély például nagy valószínúséggel nem fog megegyezést kezdeményezni vagy pert indítani egy túlzottan hangos szórakozóhely vagy közlekedési vállalat ellen, még akkor sem, ha erre egyébként jogosult lenne. Mindez pedig felvetheti az igényt a hatékonyabb állami jelenlétre mind a tulajdonjogok specifikációja, mind a jogok alacsonyabb tranzakciós költség mentén történô érvényesíthetôsége, mind pedig az externáliáktól való nagyobb fokú intézményes védelem megteremtése terén. 
Veres Pál - Golovics József: Az ingatlantulajdont érô negatív externáliák problémája...

\section{NegatíV EXTERnÁliák éS INTÉZMÉnYES VÉdELEM}

Az előzố fejezetben felvetett intézményes védelem szükségessége számos olyan negatív externália kapcsán kívánatosnak túnhet, amelyek esetében jelenleg a tulajdonosok, észszerú keretek között, a „tứrésen” kívül nem tehettek mást. A teljesség igénye nélkül, példaként említünk néhány ilyen negatív externális hatást (hangsúlyozandó, hogy itt elsősorban az újonnan, az ingatlan megvásárlásához képest időben késôbb megjelenô hatásokra kívánunk fókuszálni):

a) a külsố zajhatás hangerejének, tartósságának, ismétlódésének, napszakos és egyéb jellemzôiinek szignifikáns megváltozása; ${ }^{5}$

b) birtokháborítás kockázatának növekedése, illetve a lakóingatlan környezete általános közbiztonságának a romlása;

c) az ingatlan használatát, múszaki állapotát érdemben befolyásoló talajmozgások megjelenése (közeli építkezés földmunkái, jelentôsen felerősödő teherforgalom stb.);

d) az ingatlan használatát, mûszaki állapotát érdemben befolyásoló vízügyi kockázatok megjelenése (vízbetörés csatornarendszerből, árvízi fenyegetettség növekedése stb.);

e) az ingatlan használatát, forgalomképességét kedvezôtlenül befolyásoló központi és helyi önkormányzati döntések;

f) a környezet megváltozásából következố tûz, robbanás, vízzel árasztás és egyéb kockázatok, események szignifikáns növekedése.

Hangsúlyozandó, hogy a fenti példák többségében az externáliák forrása lehet más ingatlantulajdonosok (magánszemélyek, vállalkozások) magatartása, vagy akár központi kormányzati, illetve önkormányzati döntés is. Megjegyzendô továbbá, hogy ezen tényezôknek a kedvezô irányú változása - tehát a pozitív externália - sem zárható ki.

Bármilyen típusú és mélységú intézményes védelemről gondolkodjunk is a fenti externáliák kapcsán, a korábban bemutatottak tükrében a jogok minél pontosabb specifikálása, tartalmának minél pontosabb meghatározása (lehetôség szerint a tranzakció során) fontos elemként szolgálhat. Ez teremti meg ugyanis az alapját annak, hogy a késóbbiekben a külsô hatásra bekövetkezô változásokat azonosítani, mérni s végsố soron kezelni is lehessen. Ehhez az alapintézmény a szerzódés, illetve annak mellékletei lehetnek. Amennyiben például - a fent tárgyaltakhoz hasonlóan az energiatanúsítvány mintájára - jogszabályi kötelezettséggel kellene a szerzett jogosultságok tartalmát pontosabban és lehetôség szerint mérhetốbben dokumentálni, az az eladó és a vevô közötti késóbbi jogvita bírósági útra terelése esetén is referenciapontként szolgálhatna. A szerzett jogosultságok minél pontosabb dokumentálása emellett a késôbb keletkezố externáliák igazságszolgáltatás révén történố kezelésében is fontos szerepet játszanának. Mivel azonban a jogok és a jog tartalmának pontosabb specifikálása s a pusztán decentralizált megoldás kapcsán is komoly aggályok vetôdnek fel (lásd a korábbi érveket a specifikálás, illetve a kikényszerítés során fellépố tranzakciós költségekról, valamint a járadékforrás keletkeztetésérôl), ezért megfontolandó lehet az ingatlantulajdonosok és nem tulajdonosok viszonyát szabályozó, formális intézményi (jogi) keretek fejlesztése is. Ennek eredménye egy ezen viszonyra vonatkozó irányítá- 
si rendszer megalkotása lehet - természetesen figyelembe véve, hogy ennek számos eleme már létezik a polgári jogban. Ehhez a fogyasztóvédelemben már eredményt elért békéltetés intézménye - természetesen a további hatékonyságemelés és tranzakciósköltség-csökkentés lehetôségét szem elôtt tartva - tanulmányozásra érdemes lehet. A jelenlegi jogi környezetben ugyanis több problémás elem kiemelhetô (a teljesség igénye nélkül):

a) Az állam szerepe tekintetében összeférhetetlenség jelenik meg, amennyiben az állam maga is forrása a negatív külsố hatásoknak - ugyanakkor ezek kezelése állami feladat is.

b) A jogszabályok jelentôs része túlságosan általános, illetve differenciálatlan formában szól jogosultságokról.

c) A jog nem védi kellôen a tulajdonosokat az állam részérôl (vagy a kifejezetten állami aktus nyomán keletkezô) negatív externális hatások ellen.

d) A megfelelô szabályozás hiánya az állam részérôl érố pozitív externális hatások révén opportunista járadékvadász magatartásra ösztönözheti a tulajdonosokat. ${ }^{6}$

e) A jogosultságot ért sérelem esetén az intézményrendszer nem segíti a probléma alacsony tranzakciós költséggel történô megoldását, s döntôen az igen magas terhekkel járó, a „hétköznapi ember” számára kilátástalannak tûnô bírósági útra „terel”.

A külsố externális hatásokkal összefüggố viták rendezése tehát a jogok specifikálása után a tényleges változások mérése-dokumentálása révén teljes vagy részbeni, végleges vagy időleges közfinanszírozással, tehát a jogsérelmet szenvedő mentesítésével képzelhetô el. Az ugyancsak fentebb javasolt irányítási rendszer a lehetséges tulajdonjogi sérelmek definiálásával, a mértékek meghatározásával, az eljárás pontos leírásával és az eljárás finanszírozásával adhatna intézményes keretet a jogsérelem orvoslásának, illetve terhelné a költséget a jogsérelem okozójára. Mindennek azonban alapvetô feltétele, hogy a jogok érvényesíthetôsége minden érintett számára alacsony tranzakciós költséggel - tehát valamennyi állampolgár számára észszerú és belátható keretek között - elérhetô legyen. Ennek hiányában ugyanis a jogosultságok mégoly fontosnak vélt pontos specifikációja is értelmét veszítheti, s mind szubjektív (tehát az érintettek szemszögéból nézve), mind objektív szempontok mentén is csak a tranzakciós költségek felesleges növekedését eredményezné.

\section{ÖSSZEFOGLALÁS，KÖVETKEZTETÉSEK}

Tanulmányunk céljaként azt határoztuk meg, hogy felhívjuk a figyelmet a tulajdonjog mint szerzett dologi jogosultság védelmére a jog megszerzése utáni idóben, különösen a negatív externáliákkal szemben. Mint azt a vonatkozó elméletek alapján bemutattuk, a problémák kezeléséhez mind a tulajdonjogok pontos specifikációja, mind a vonatkozó tranzakciós költségek csökkentése elengedhetetlen feltétel. A hazai helyzetre kivetítve mindezt, megállapítottuk, hogy a hatékonyabb állami jelenlét - a jogosultságok definiálása, a jogérvényesítés megkönnyítése és az intézményes védelem megteremtése terén - érdemben hozzájárulhatna az állampolgárok bizonytalanságérzetének a csökkentéséhez, s ezáltal a jólétük növeléséhez is. 
Tanulmányunk legfontosabb üzenete mindazonáltal az, hogy az ingatlantulajdont érô externáliák kérdése „ingoványos” terep, amellyel foglalkozni kell. Különösen igaz ez napjainkban, ahol a felgyorsult technológiai, illetve szocioökonómiai változások, s az erre reflektáló kormányzati döntések egyik napról a másikra gyakorolhatnak drasztikus mértékú jóléti hatásokat a „gyanútlan” polgárokra. Mindezen változásoknak azonban a pozitív aspektusai is felhasználhatók a hatások enyhítésére. Ilyenek lehetnek például a technológiai fejlôdés és digitalizáció révén elérhetô mérési, illetve tranzakciósköltség-csökkentési lehetôségek kihasználása, amire az ingatlanokat érô externáliák decentralizált, valamint állami közbenjárással történô kezelése esetén is tér nyílhat.

\section{JEGYZETEK}

1 Jelen kutatás az Európai Unió, Magyarország és az Európai Szociális Alap társfinanszírozása által biztosított forrásból, az EFOP-3.6.2-16-2017-00017 azonosítójú Fenntartható, intelligens és befogadó regionális és városi modellek címú projekt keretében jött létre.

2 A tanulmány szerzôi a Budapesti Corvinus Egyetem Összehasonlító és Intézményi Gazdaságtan Tanszékének munkatársai, ahol többek között az elmúlt években bevezetett „Intézményi közgazdaságtan” tárgy oktatói, s a tanszéki kollektíva által írt tankönyv (Bara-Hámori, 2019) tulajdonjogokról szóló fejezetének (Golovics-Veres, 2019) szerzôi. E fejezet jelen tanulmány elemzésének is háttereként szolgál.

3 Ezek kapcsán rendre s gyakran fokozottan felmerülhetnek azok a problémák, amelyeket a tanulmányban a magántulajdon kapcsán tárgyalunk, ám ezek részletes elemzése meghaladná jelen írás kereteit.

4 Ezen paraméterek egy részének a mérése természetesen akár a vevố részérôl is megvalósítható lenne indirekt, privát eszközökkel, azonban ez valamennyi jellemzőre nem terjedne ki, illetve amellett, hogy a mérés költsége magas(abb) lenne, privát jellege miatt a késôbbi alkukban sem képezhetne hivatkozási alapot.

5 Noha a zaj kérdése valójában az alaposabban szabályozott externáliák közé tartozik, mégis számos jel utal a kérdés aggályosságának voltára. A napi sajtóban rendszeresen találkozhatunk olyan esetekkel, amelyekben a lakosok szerint egyes szórakozóhelyek elviselhetetlen zajt bocsátanak ki, ám mégis tehetetlenek ez ellen. A tapasztalt zajszint ugyanis sokszor történetesen épp a jogszabályi határértéken belül van, s az intézményi környezet sem támogató a probléma kezelése szempontjából.

${ }_{6}^{6}$ Bár tanulmányunkban a terjedelmi korlátok okán kerültük a pozitív externáliák tárgyalását, itt kiemelendô, hogy ennek átgondolása is fokozott fontossággal bírhat. Példaként említhetünk olyan eseteket, amelyekben egy esetleges (például építkezési célú) kormányzati döntés hatására - mintegy pozitív externáliaként - drasztikusan megnố a környezô ingatlanok ára. Világos, hogy ezen értéknövekedés mögött szintén nincs valódi piaci teljesítmény, s így az ilyen esetek opportunista spekulációra, járadékvadász-tevékenységre ösztönözhetnek, ami a morális megfontolásokon túl jóléti szempontok alapján is felvetheti a szabályozás lehetôségét.

\section{FELHASZNÁLT IRODALOM}

Bara Zoltán - Hámori Balázs (szerk.) (2019): Intézményi közgazdaságtan. Kézirat (megjelenés alatt).

Bartus Gábor - Szalai Ákos (2014): Környezet, jog, közgazdaságtan. Környezetpolitikai eszközök, környezet-gazdaságtani modellek és joggazdaságtani magyarázatok. Pázmány Press, Budapest.

Coase, Ronald H. (1960): The Problem of Social Cost. The Journal of Law E Economics, Vol. 3, No. 1, 1-44, https://doi.org/10.1007/s10657-010-9200-0.

Demsetz, Harold (1967): Toward a Theory of Property Rights. The American Economic Review, Vol. 57, No. 2, 347-359. 
Golovics József - Veres Pál (2019): A tulajdonjogok elmélete. In: Bara Zoltán - Hámori Balázs (szerk.): Intézményi közgazdaságtan. Kézirat (megjelenés alatt).

Hart, Oliver (2006): Vállalatok, szerzôdések és tôkeszerkezet. Nemzeti Tankönyvkiadó, Budapest.

Hohfeld, Wesley N. (1913): Some Fundamental Legal Conceptions as Applied in Judicial Reasoning. The Yale Law Journal, Vol. 23, No. 1, 16-59, https://doi.org/10.2307/785533.

Hohfeld, Wesley N. (1917/2000): Alapvetô jogi fogalmak a bírói érvelésben. In: Szabó Miklós - Varga Csaba (szerk.): Jog és nyelv. Osiris Kiadó, Budapest, 59-96.

KSH (2018): Mikrocenzus 2016. 7. Lakáskörülmények. Központi Statisztikai Hivatal, Budapest, www.ksh.hu/ docs/hun/xftp/idoszaki/mikrocenzus2016/mikrocenzus_2016_7.pdf.

North, Douglass C. (2010): Intézmények, intézményi változás és gazdasági teljesítmény. Helikon Kiadó, Budapest.

Pejovich, Svetozar (1992): A tulajdonjogok közgazdaságtana. Közgazdasági és Jogi Könyvkiadó, Budapest.

Tullock, Gordon (2005): The Theory of Public Choice. In: Tullock, Gordon - Seldon, Arthur - Brady, Gordon L. (eds.): Government Failure. A Primer in Public Choice. Cato Institute, Washington, 3-79.

Weimer, David L. - Vining, Aidan R. (2011): Policy Analysis. Concepts and Practice. Longman, Boston.

Williamson, Oliver E. (1985): The Economic Institutions of Capitalism. Firms, Market, Relational Contracting. Free Press, New York. 